\title{
Autoimmune Hepatitis- Primary Biliary Cholangitis Overlap Triggered by Geftinib
}

\author{
Sridhar Sundaram ${ }^{1 *}$ and Vaneet Jearth ${ }^{2}$ \\ ${ }^{1}$ Department of Gastroenterology, Seth GS Medical College and KEM Hospital, India \\ ${ }^{2}$ Department of Digestive Diseases and Clinical Nutrition, Tata Memorial Centre, India
}

Submission: February 21, 2019; Published: June 12, 2019

"Corresponding author: Sridhar Sundaram, Assistant Professor, Department of Gastroenterology, Seth GS Medical College and KEM Hospital, Acharya Donde Marg, Mumbai, India

\begin{abstract}
Tyrosine kinase inhibitors (TKIs) are commonly used anti-neoplastic drugs. Although hepatotoxicity is known with use of TKIs, there are only few reports of Autoimmune hepatitis after use of these agents. Geftinib is an Epidermal Growth Factor Receptor (EGFR) tyrosine kinase inhibitor commonly used for metastatic lung cancer. Although hepatotoxicity is known with its use, we report a rare case of Autoimmune Hepatitis- Primary biliary cholangitis overlap triggered after use of Geftinib.
\end{abstract}

Keywords: Tyrosine kinase inhibitors; AIH-PBC overlap; Geftinib; Nitrofurantoin; Minocycline; Bile duct injury; Anti-neoplastic medications; Idiosyncratic; Liver failure; Mitochondrial fatty acid oxidation

Abbreviations: TKIs: Tyrosine Kinase Inhibitors; EGFR: Epidermal Growth Factor Receptor; DI-AIH: Drug Induced Autoimmune Hepatitis; DILI: Drug Induced Liver Injury; AST: Aspartate Transaminase; ALT: Alanine Transaminase; GGT: Gamma Glutamyl Transpeptidase; ANA: AntiNuclear Antibody; AMA: Anti-Mitochondrial Antibody; ASMA: Anti-Smooth Muscle Antibody

\section{Introduction}

Drug induced Autoimmune Hepatitis (DI-AIH) is a known entity, comprising $9 \%$ of all AIH cases. Drugs like Nitrofurantoin, Minocycline, Alpha-methyl dopa have been reported as common agents responsible for DI-AIH [1]. Statins have rarely been reported presenting with AIH [2]. Bile duct injury with cholestasis is commonly a presenting feature of immuno-allergic Drug induced liver injury (DILI). Rarely drugs have been reported to trigger overlap between AIH and Primary biliary cholangitis [3]. Tyrosine kinase inhibitors (TKI) are commonly used antineoplastic medications. There is a $5-25 \%$ risk of hepatotoxicity with this group, while a $0.8 \%$ risk of liver failure [4]. The mechanism of injury is most often idiosyncratic, likely affecting the mitochondrial fatty acid oxidation, with resolution after stopping medications.

\section{Case Report}

56-year-old male, nonalcoholic, with no comorbid illnesses, known case of Adenocarcinoma of the lung (EGFR Positive) with skeletal metastases and malignant pleural effusion was started on Geftinib $250 \mathrm{mg}$ daily as palliative chemotherapy. His creatinine was $0.8 \mathrm{mg} \%$ prior to starting medications. His liver functions tests showed Bilirubin of $0.68 \mathrm{mg} \%$, Albumin of $3.4 \mathrm{~g} \%$, Alkaline Phosphatase (ALP) of $131 \mathrm{U} / \mathrm{L}$ (Normal <120 U/L), Aspartate transaminase (AST) of $35 \mathrm{U} / \mathrm{L}$ (Normal $<40 \mathrm{U} / \mathrm{L}$ ) and Alanine Transaminase (ALT) of $42 \mathrm{U} / \mathrm{L}$ (Normal $<40 \mathrm{U} / \mathrm{L}$ ). Complete blood count was normal.

On subsequent follow up at 3 months, there was good response to medications, however, AST, ALT and ALP were elevated twice upper limit of normal. He was continued on Geftinib considering its propensity of hepatotoxicity and was reviewed after 2 months. On follow up, Bilirubin was $0.7 \mathrm{mg} \%$, AST was $220 \mathrm{U} / \mathrm{L}$, ALT was $169 \mathrm{U} / \mathrm{L}$, ALP was $1242 \mathrm{U} / \mathrm{L}$, Gamma Glutamyl transpeptidase (GGT) was $550.8 \mathrm{U} / \mathrm{L}$ (normal <50 U/L), Albumin was $3.4 \mathrm{~g} \%$, while globulin had increased to $4.9 \mathrm{~g} \%$ with INR of 1.1 . There was no eosinophilia on differential blood count. Geftinib was with-held and patient was referred to the Hepatology clinic for evaluation. Abdominal ultrasound showed mild hepatomegaly with no biliary dilatation. After observing for 2 weeks, with no subsequent decrease in liver function tests, and workup for Hepatitis A, B, C and $\mathrm{E}, \mathrm{EBV}$ and $\mathrm{CMV}$ negative, autoimmune workup was planned.

ANA (Anti-nuclear antibody) was 1:1280 titer reactive with cytoplasmic pattern. AMA (Anti-mitochondrial antibody M2) was reactive with 1:80 titer. ASMA (Anti-smooth muscle antibody) was negative. Serum total IgG levels were $3310 \mathrm{mg} \%$ (normal till 1600 $\mathrm{mg} \%$ ). He then underwent liver biopsy, which showed marked 
portal inflammation with severe interface hepatitis predominantly consisting of plasma cells with emperipolesis and rosetting. There was bile duct destruction with ill formed granulomas with lymphocytes and plasma cells (Figure I \& 2). No steatosis or ballooning degeneration was seen. There was no significant fibrosis. In view of histopathologic findings and autoimmune workup compatible with diagnosis of AIH-PBC overlap, patient was started on Prednisolone (1 mg/kg) and Urso-deoxycholic acid (600 mg/day). On follow up after 2 weeks, the AST and ALT had normalized while the ALP had reduced to $218 \mathrm{U} / \mathrm{L}$. The patient on follow up after 3 months had persistently normal liver function tests. The steroids were tapered and UDCA was continued. ANA and AMA titers remained high. Patient was not re-challenged with Geftinib and alternative chemotherapy was planned.
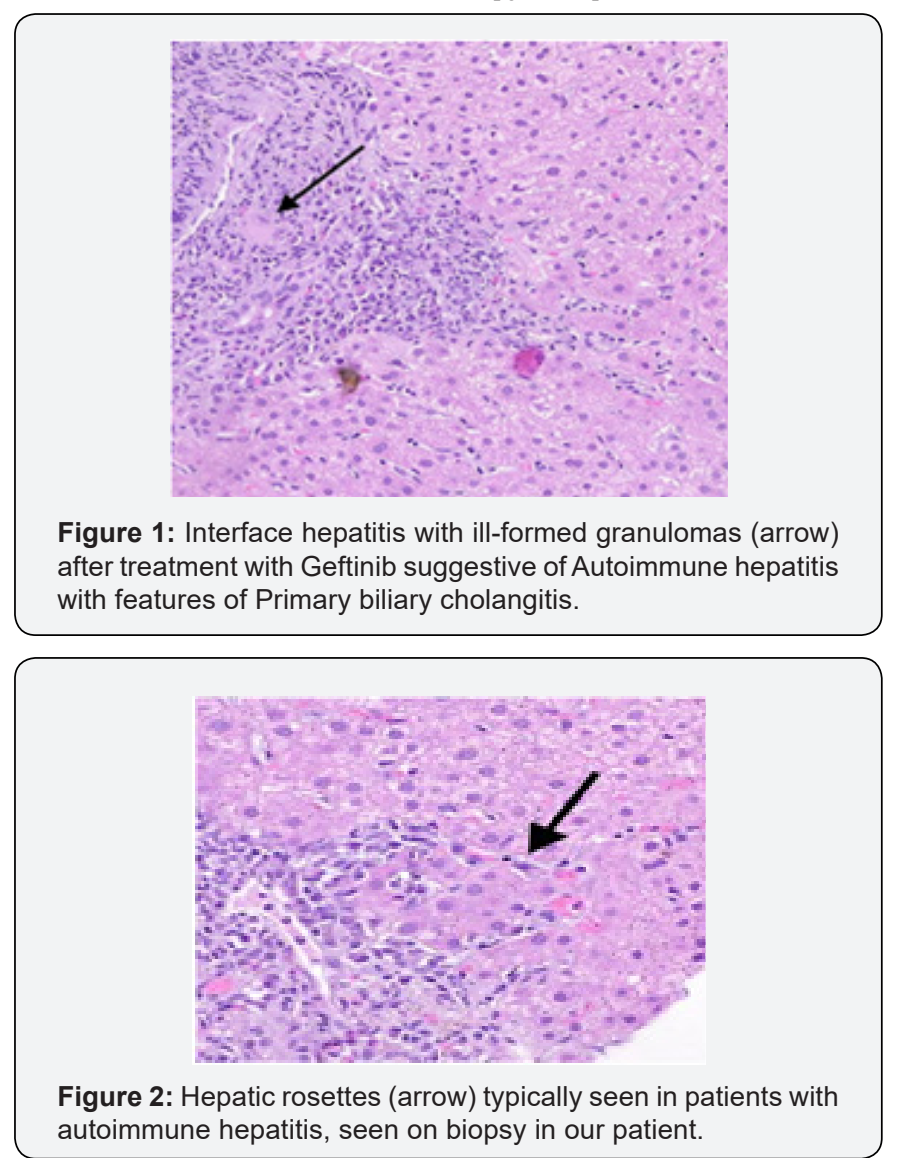

\section{Discussion}

We presume our case to be of AIH-PBC overlap triggered by Geftinib, considering the normal tests prior to starting the medication, lack of viral etiology and temporal correlation of derangement in liver function tests with starting of medication. Tyrosine kinase inhibitors like Imatinib are known to cause immune mediated liver injury with response to prednisolone in previous reports [5]. However, previous reports of DI-AIH or features of AIH-PBC overlap are published with use of Geftinib.

Geftinib is an Epidermal growth factor receptor (EGFR) tyrosine kinase inhibitor, commonly used in metastatic adenocarcinoma of the lung associated with improved survival and quality of life over other chemotherapy [6]. Hepatotoxicity is known with Geftinib leading to Grade 3 CTCAE hepatotoxicity in $6.5 \%$ of treated patients. Most patients recover after stopping Geftinib and low doses or alternate day regimen can be continued. Patients with previous chemotherapy are at increased risk of hepatotoxicity [7]. Also, there is evidence to suggest that the hepatotoxicity associated with Geftinib increases as duration of use increases [8]. The mechanisms of Geftinib hepatotoxicity are poorly understood. Geftinib is metabolized by CYP2D6 and lower levels of this enzyme in patients with CYP3A4 inhibition may be responsible for the hepatotoxicity. Genetic background with low CYP2D6 activity may also lead to increase in Geftinib levels and subsequent hepatotoxicity [9].

Being the agent of choice for metastatic adenocarcinoma of lung with EGFR positivity, there are an increasing number of patients who are receiving Geftinib. Although hepatotoxicity is known with Geftinib, persistence of activity on liver function tests warrants investigation into ruling out autoimmune liver injury. Also, further data on mechanisms of hepatotoxicity of various tyrosine kinase inhibitors is needed, with increasing use of these medications in the ever-expanding armamentarium against various cancers.

\section{References}

1. Castiella A, Zapata E, Lucena MI, Andrade RJ (2014) Drug-induced autoimmune liver disease: A diagnostic dilemma of an increasingly reported disease. World J Hepatol 6(4): 160-168.

2. Russo MW, Scobey M, Bonkovsky HL (2009) Drug-induced liver injury associated with statins. Semin Liver Dis 29(4): 412-422.

3. Nakayama S, Murashima N (2011) Overlap syndrome of autoimmune hepatitis and primary biliary cirrhosis triggered by fluvastatin. Indian J Gastroenterol 30(2): 97-99.

4. Ghatalia P, Je Y, Mouallem NE, Nguyen PL, Trinh QD, et al. (2015) Hepatotoxicity with vascular endothelial growth factor receptor tyrosine kinase inhibitors: A meta-analysis of randomized clinical trials. Crit Rev Oncol Hematol 93(3): 257-276.

5. Dhalluin-Venier V, Besson C, Dimet S, Thirot-Bibault A, Tchernia G, et al. (2006) Imatinib mesylate-induced acute hepatitis with autoimmune features. Eur J Gastroenterol Hepatol 18(11): 1235-1237.

6. Keedy VL, Temin S, Somerfield MR, Beasley MB, Johnson DH, et al. (2011) American Society of Clinical Oncology provisional clinical opinion: epidermal growth factor receptor (EGFR) Mutation testing for patients with advanced non-small-cell lung cancer considering firstline EGFR tyrosine kinase inhibitor therapy. J Clin Oncol 29(15): 21212127.

7. Sugiura Y, Nemoto E, Kawai O, Ohkubo Y, Fusegawa H, et al. (2013) Gefitinib frequently induces liver damage in patients with lung adenocarcinoma previously treated by chemotherapy. Lung Cancer (Auckl) 4: 9-14.

8. Wang J, Wu Y, Dong M, He X, Wang Z, et al. (2016) Observation of hepatotoxicity during long-term gefitinib administration in patients with non-small-cell lung cancer. Anticancer Drugs 27(3): 245-250.

9. Takimoto T, Kijima T, Otani Y, Nonen S, Namba Y, et al. (2013) Polymorphisms of CYP2D6 gene and gefitinib-induced hepatotoxicity. Clin Lung Cancer 14(5): 502-507. 
This work is licensed under Creative Commons Attribution 4.0 License

DOI: 10.19080/ARGH.2019.13.555856
Your next submission with JuniperPublishers will reach you the below assets

- Quality Editorial service

- Swift Peer Review

- Reprints availability

- E-prints Service

- Manuscript Podcast for convenient understanding

- Global attainment for your research

- Manuscript accessibility in different formats (Pdf, E-pub, Full Text, audio)

- Unceasing customer service

Track the below URL for one-step submission https://juniperpublishers.com/online-submission.php 